\title{
A íntima dependência mútua entre fato e valor
}

Por muito tempo, os filósofos sustentaram que a verdade de Deus jamais poderia ser a nossa própria verdade ${ }^{1}$. Entretanto, gostaríamos de imaginar que ela é. Em muitos domínios de investigação prática da vida social, tais como o jornalismo, frequentemente falamos como se pudéssemos possuir a verdade - pelo menos em princípio, senão plenamente na prática - na forma de uma única versão que corresponda às coisas e aos eventos de um determinado mundo, um relato despido de interesses individuais, de valor social ou mesmo da linguagem. Em outras palavras, gostaríamos de imaginar um relato livre de nós mesmos.

Talvez falemos da verdade desta maneira porque acreditamos que ela é inspiradora. Com essa concepção, parece que estamos fixando para nós mesmos um alto padrão na condução de nossas atividades. Porém, ao mesmo tempo, sabemos muito bem como lidar com a impossibilidade de alcançarmos esse padrão. Os repórteres investigativos, por exemplo, frequentemente afirmam que precisam descobrir o que realmente aconteceu em situações nas quais se presumem injustiças. E apesar disso, eles sabem muito bem como lidar com a impossibilidade - e portanto a irrelevância - de acessar o que "realmente aconteceu". Além disso, eles dizem que precisam primeiro

Do original "The intimate interdependence of fact and value", publicado como o capítulo 6 do livro Custodians of conscience: investigative journalism and public virtue. Direitos autorais concedidos pela Columbia University Press. Traduzido por Dermeval Aires Júnior. Revisão da tradução por Luis Felipe Miguel. 
reunir os fatos, para então (e apenas então) escreverem a história, como se os fatos fossem observações científicas isoladas a partir das quais eles induzirão uma teoria. E ainda assim, esses repórteres sabem muito bem como lidar com a constituição mútua entre fato e narrativa, na qual um elemento é necessário ao outro. Por fim, eles podem afirmar que devem separar fato e valor em suas histórias. E ainda assim, sabem bem como estabelecer fatos e contar histórias que não existem independentemente de valores. Em outras palavras, esses jornalistas sabem produzir relatos que estão dispostos a chamar de "verdadeiros" a despeito de sua cultura profissional determinar um padrão impossível de alcançar para a Verdade.

\section{Dizer a verdade como esforço prático}

Aqui, pretendemos provocar uma discussão a respeito da verdade no jornalismo - mas, certamente, sem negar que a verdade existe. Ao contrário, pretendemos enfatizar a incongruência entre as concepções ingênuas, embora inspiradoras, de verdade, por um lado, e a prática efetiva do jornalismo, de outro. Nossa intenção é valorizar, não anular, o trabalho daqueles que buscam conhecer e relatar a verdade sobre o mundo social. Quando um historiador, com a mesma intenção, provoca discussão ao afirmar que o que aconteceu no passado é irrelevante para o trabalho dos historiadores, o seu ponto se transforma em algo bastante apreciativo e prático (Goldstein, 1976). O passado, precisamente porque já passou, está acessível apenas indiretamente por meio dos seus rastros: registros, documentos, artefatos, a memória viva. Portanto, o padrão para a validação da verdade de afirmações sobre o passado não pode ser a correspondência entre o que é declarado e o que realmente ocorreu. O padrão só pode ser algum grau de corroboração entre os rastros disponíveis - e isso costuma demandar bastante trabalho árduo. O mesmo acontece com os jornalistas.

Para que dizer a verdade seja entendido como um esforço prático, a verdade não deve ser conceituada e analisada apenas como uma condição que algumas afirmações precisam cumprir, e sim como o resultado de um processo que permite gerar e defender essas afirmações. As afirmações que os historiadores e jornalistas desejam chamar de "verdadeiras" são o produto de um árduo trabalho que inicia com a localização e a comparação de quaisquer rastros deixados pelo que aconteceu. Paul Ricœur comentou a respeito dessa fase do processo: 
Entender o passado nos seus rastros documentais, e através deles, é realizar uma observação no sentido forte da palavra - pois observar nunca significa apenas registrar um fato bruto... A investigação do historiador não apenas traz à luz a dignidade de um documento significativo, mas ela também ergue o próprio passado à dignidade de um fato histórico. O documento não era um documento antes de o historiador aparecer para fazer-lhe uma pergunta. Assim, com base em sua observação, o historiador estabelece um documento, por assim dizer, por trás de si, e dessa forma estabelece os fatos históricos. (Ricœur, 1965, p. 23)

Mas como os historiadores ou jornalistas sabem quais perguntas fazer? A resposta é que, em parte, eles sabem quais perguntas fazer porque já conhecem a história. Ninguém apresentou esse ponto de maneira mais provocadora do que Hayden White. Seguindo R. G. Collingwood, White afirmou que "os historiadores chegam às suas evidências imbuídos de uma noção das possíveis formas que diferentes tipos de situações reconhecidamente humanas podem assumir" (White, 1978, p. 83; grifos no original). Por sua vez, a forma de qualquer uma dessas situações - quer dizer, a história - direciona a busca do historiador pelos fatos daquela situação. "São os tipos de discursos figurativos que ditam as formas fundamentais dos dados a serem estudados", afirma White. "Isso significa que o molde das relações que parecerão ser inerentes aos objetos de um campo na verdade terá sido imposto sobre o campo pelo investigador no seu próprio ato de identificar e descrever os objetos que ele encontra ali” (White, 1978, p. 95). Assim são constituídos os fatos e as histórias. Ademais, para White, fatos e histórias só podem ser constituídos dentro de um sistema de valores.

Vale a pena saborear uma passagem da coletânea de ensaios de White intitulada The content of form ["O conteúdo da forma"], pois ela sustenta nossa visão, ao nos voltarmos da questão de como os fatos são organizados dentro das histórias para a questão de como os fatos e histórias são conhecidos, pura e simplesmente.

Os eventos efetivamente registrados na narrativa parecem ser reais precisamente na medida em que eles pertencem a uma ordem da existência moral, assim como eles derivam o seu significado da sua colocação em meio a essa ordem. É porque os eventos descritos conduzem ao estabelecimento de uma ordem social, ou fracassam em fazê-lo, que eles encontram na narrativa um lugar que atesta a sua realidade. (White, 1987, p. 23) 
E dada a base moral da narrativa, os fatos também possuem uma base moral. Os valores, mediados pela forma da narrativa, desempenham um papel central no conhecer e descrever os fatos.

Afirmar, como afirmamos, que:

1. na investigação prática, a verdade é o resultado de um processo de lidar com as evidências, não de lidar com a "realidade";

2. os fatos e as histórias são mutuamente constituídos ao longo desse processo;

3. os valores são inerentes ao processo,

não é afirmar que nenhuma condição é imposta sobre o processo. Por exemplo, algumas condições rígidas são impostas por aquilo que Melvin Pollner acertadamente chamou de "razão mundana". Valendo-se da fenomenologia de Husserl e Merleau-Ponty, Pollner argumentou que a racionalidade prática do dia-a-dia tem alguns pressupostos fundamentais e não-questionados - de fato, inquestionáveis - sobre qualquer relato do mundo que possa ser considerado verdadeiro. Entre esses pressupostos, de acordo com ele, estão as expectativas de que a realidade é sempre coerente, não-contraditória e determinada (em outras palavras, distinta, definida, ou decidida, e, portanto, conclusivamente averiguável, pelo menos em princípio) (Pollner, 1987, p. 26).

Como esses pressupostos são invocados antes de qualquer tentativa de determinar, descrever ou até mesmo observar a realidade, eles são mais bem caracterizados como idealizações da realidade. Tais idealizações nunca são questionadas quando os relatos da suposta realidade estão em conflito entre si, como frequentemente ocorre na rotina mundana, digamos, de um tribunal de trânsito, que é o local de onde Pollner retira os seus exemplos. A razão mundana sempre pressupõe que essas idealizações devem ser mantidas, e que relatos distintos não estariam em conflito se tivessem surgido sob as mesmas circunstâncias (ou seja, a partir das mesmas condições de observação e das mesmas motivações dos observadores). E quando os relatos entram efetivamente em conflito, a razão mundana proporciona um repertório vasto, ainda que culturalmente determinado, de estratégias para explicar quaisquer potenciais disjunções na realidade. Assim, a lógica da razão mundana subjaz a muitos procedimentos socialmente aprovados que se destinam a encontrar, explicar, punir e corrigir aquilo que deve ser uma mentira ou uma falha. Seguindo o psiquiatra R. D. Laing, Pollner caracteriza esses procedimentos 
como "a política da experiência". Os jornalistas, assim como os historiadores e os juízes dos tribunais de trânsito, são habilidosos políticos.

\section{Uma verdade em meio ao realismo e ao relativismo}

Os jornalistas normalmente respondem com modéstia quando são perguntados se encontraram a verdade a respeito de uma história, pois reconhecem os constrangimentos psicológicos, organizacionais e políticos que atuam sobre o seu trabalho. Entretanto, eles também falam como se houvesse algo da verdade de Deus que eles poderiam ter encontrado, não fosse por esses constrangimentos. Os jornalistas, assim como a maioria das pessoas na maior parte do tempo, tendem a ser aquilo que o filósofo Hilary Putnam chamou de "realistas metafísicos" ou "externalistas". De acordo com Putnam, os externalistas supõem que "o mundo consiste de uma totalidade fixa de objetos que existem de forma independente da mente", e que "existe uma única descrição verdadeira e completa do 'mundo tal como ele é”'. Para dizermos a verdade, devemos fazer uma afirmação que corresponde precisamente ao mundo tal como ele é. E para conhecermos a verdade, devemos encontrar uma perspectiva externa no mundo - "um ponto de vista do Olho de Deus", como Putnam a caracteriza (Putnam, 1981, p. 49).

A concepção de Putnam da verdade - "internalismo" - postula que uma questão sobre o que é verdade a respeito do mundo deve ser respondida apenas internamente a uma descrição ou teoria do mundo. A verdade, em uma visão internalista, é uma "coerência ideal das nossas crenças umas com as outras e com as nossas experiências, tal como que essas experiências são, elas mesmas, representadas no nosso sistema de crenças - e não uma correspondência com 'estados de coisas' independentes da mente ou do discurso", escreveu ele. "Não há um ponto de vista do Olho de Deus que possamos conhecer ou imaginar de maneira útil; o que existe são apenas os diversos pontos de vista das pessoas, refletindo diversos interesses e propósitos aos quais suas descrições ou teorias servem" (Putnam, 1981, p. 49-50; grifos no original).

O internalismo de Putnam se contrapõe ao externalismo ingênuo, não porque nega que existe um mundo real, e sim porque mantém que os objetos nesse mundo não podem existir para nós independentemente de nossos sistemas conceituais. "Nós separamos o mundo em objetos ao introduzirmos um esquema ou outro de descrição", argumentou. "Os objetos $e$ os signos são igualmente internos ao esquema da descrição, e por isso é possível di- 
zer o que combina com o que" (Putnam, 1981, p. 52). Ao mesmo tempo, o internalismo se contrapõe ao relativismo superficial, não por insistir em um único sistema conceitual correto, e sim por reconhecer que nem todos os sistemas conceituais são igualmente adequados. "O internalismo não nega que existem insumos experienciais ao conhecimento; o conhecimento não é uma história sem outros constrangimentos além da coerência interna", defendeu Putnam, "mas ele nega, sim, que haja qualquer insumo que não seja moldado, em alguma medida, pelos nossos conceitos, pelo vocabulário que usamos para relatá-los e descrevê-los, ou qualquer insumo que aceite uma única descrição, independentemente de escolhas conceituais" (Putnam, 1981, p. 54; grifos no original).

Dessa forma, o padrão para a avaliação da verdade não é uma correspondência rígida e sim uma coerência realista e flexível - e bastante humana. Para Putnam, os padrões para avaliar a aceitabilidade racional de uma afirmação ou de um sistema de afirmações (por exemplo, uma teoria ou história) estão amplamente ligados ao encaixe das crenças teóricas e/ou experienciais entre si. E, por sua vez, os padrões para determinar a precisão de um encaixe estão amplamente ligados aos interesses, valores e desejos humanos. Nossas concepções de coerência e encaixe "dependem de nossa biologia e de nossa cultura; eles não são de forma alguma 'livres de valores", afirmou Putnam. "Mas elas são nossas concepções, e são concepções de algo real” (Putnam, 1981, p. 55).

Um elemento central na concepção de Putnam sobre a verdade é a ideia de que qualquer esquema conceitual ao qual as crenças aderem inclui valores. Ele resumiu tal ideia da seguinte maneira:

$\mathrm{O}$ argumento, em suma, era de que fato (ou verdade) e racionalidade são noções interdependentes. Um fato é algo em que é racional acreditar (...). E eu argumentei que ser racional envolve critérios de relevância, bem como critérios de aceitabilidade racional, e que todos os nossos valores estão envolvidos em nossos critérios de relevância. A decisão de que uma imagem do mundo é verdadeira (ou verdadeira à luz do que sabemos hoje, ou "tão verdadeira como qualquer outra coisa") e responde às questões relevantes (tão bem quanto somos capazes de respondê-las) assenta-se sobre - e revela - o nosso sistema total de compromissos de valor. Um ser sem valores também não poderia ter qualquer fato (Putnam, 1981, p. 201).

$\mathrm{Ou}$, dito de maneira ainda mais simples, "cada fato está carregado de valores, e cada um de nossos valores carrega algum fato" (Putnam, 1981, p. 201). 
Pela perspectiva internalista, os jornalistas entram em um mundo há muito recortado em objetos por esquemas descritivos. As instituições sociais, bem como a linguagem, mantêm a realidade desse mundo. Assim, o mundo leva aos jornalistas os "fatos concretos", juntamente com os procedimentos para verificar esses fatos. Por exemplo, um incêndio - a quintessência de uma "notícia concreta" - é algo que leva a eles fatos concretos como a origem, os danos e as fatalidades, porque as instituições e a linguagem de nossa era técnica fazem com que eles vejam todos os incêndios (ou, pelo menos, todos os incêndios nos quais eles não tiverem um interesse pessoal) como uma ocorrência discreta de breve duração com causas cientificamente definidas e efeitos legalmente definidos. Alguns fatos (p.ex. fatalidades) possuem, na frase de Putnam, "claras condições de teste empírico" (ou seja, uma contagem de corpos recuperados) e outros fatos (p.ex. origens) possuem aquilo que pode ser chamado de claras condições burocráticas de teste (ou seja, o relatório oficial dos investigadores de incêndio) (Putnam, 1981, p. 159).

Para ajudar a sustentar a noção de que as notícias, pelo menos em princípio, podem sempre corresponder muito precisamente ao que realmente aconteceu, os jornalistas podem citar casos paradigmáticos de fatos concretos, como os de um incêndio. E quando são chamados a defender a veracidade sobre uma notícia específica, eles podem citar sua cuidadosa adesão aos procedimentos para reunir tais fatos. Porém, eles tipicamente não lidam com a questão de como e por que o mundo foi recortado nesses fatos específicos, e não outros, para descreverem "o incêndio". Como pensadores mundanos, eles nunca precisam questionar os esquemas de descrição com os quais vivem e trabalham.

Mesmo se a cultura institucional do jornalismo aderisse a uma concepção externalista simples da verdade, o trabalho dos repórteres investigativos proporcionaria uma interessante oportunidade de criticar tais concepções. Como os repórteres não podem sempre confiar em claras condições de teste empírico e nos procedimentos burocráticos socialmente aprovados que servem para manter a credibilidade da cobertura diária das notícias concretas, eles não conseguem defender com facilidade a veracidade de suas notícias com eloquentes referências a casos paradigmáticos de fatos concretos. Porém, eles podem defender a veracidade de seus relatórios revisando todo o árduo trabalho realizado na verificação de fatos e histórias, e, ao fazê-lo, 
revelam, mesmo que involuntariamente, o modo como fatos e histórias são mutuamente constituídos dentro de um esquema conceitual carregado de valores, que os torna tanto moralmente ordenados como verdadeiros. Para diversas revisões desse tipo sobre a prática jornalística, debruçamo-nos sobre as palavras e a obra de três ilustres repórteres e suas histórias premiadas ${ }^{2}$.

\section{A obtenção dos fatos}

Os repórteres investigativos, de uma maneira ou de outra, afirmam o seu compromisso com a ideia de que eles podem e devem descobrir o que realmente aconteceu. Mas assim como os historiadores e os juízes, eles devem se basear em documentos, registros, artefatos e memórias em seu trabalho. Sob essas condições, o processo de estabelecer a verdade não pode implicar no exame do que realmente ocorreu, seguido da elaboração do único relato correto que corresponde exatamente ao que de fato aconteceu. Em vez disso, o processo deve implicar a localização e o exame dos relatos existentes, e a elaboração de um novo relato que pode ser aceito como fidedigno. Qualquer correspondência não é entre o relato fidedigno e a realidade, e sim entre os diferentes relatos. E ao longo desse processo, os repórteres precisam trabalhar de modo a satisfazer as concepções pré-existentes sobre o formato que a realidade deve ter: coerente, determinada, não-contraditória.

É improvável que os repórteres investigativos analisem sua situação epistemológica exatamente nesses termos; porém, eles sabem lidar com a situação de maneira eficaz. A sua versão da situação seria mais desse jeito: os repórteres saem para conseguir a história, mas sabem que a única maneira de fazê-lo é conseguindo primeiro as histórias dos outros. Eles também sabem que provavelmente ouvirão diferentes histórias de diferentes fontes. Como resultado, eles esperam juntar as partes de sua história por meio de um laborioso processo de corroboração entre múltiplas fontes e tipos de evidência. Bill Marimow, por exemplo, entendeu desde o início de sua investigação sobre a unidade policial K-9 na Filadélfia que iria trabalhar com registros policiais e outros documentos, bem como com os testemunhos dos indivíduos que (em seu "esquema de descrição" particular e moralmente orientado) viriam a ser as "vítimas" em sua história. Ele também entendeu que a correspondência entre esses materiais textuais estaria longe de ser

Ettema e Glasser usaram estas mesmas notícias como exemplos no capítulo anterior do livro (N.E.). 
exata, mas de alguma forma poderia juntar as partes em um único relato dos eventos. Aqui está a maneira como ele reconstruiu sua situação epistemológica no início do trabalho:

A polícia precisa registrar uma denúncia se prender alguém, ou preparar um relatório de acidente se há um acidente. Isso é bom, porque é uma evidência independente da vítima, que pode ter contatado você, de que algo realmente aconteceu no saguão do metrô às sete e meia, que havia um policial da unidade K-9 no local, e que também havia outros policiais ali. Esse relatório, em conjunto com o relato da vítima, normalmente lhe dará toda a gama do que você pode esperar ouvir. O relato da polícia provavelmente será o conjunto de fatos mais desfavorável à vítima, e o relato da vítima será o conjunto de fatos mais desfavorável à polícia.

Teremos o trabalho de olhar esses relatos e descobrir todo o resto: registros policiais, registros judiciais, entrevistas com as vítimas e testemunhas, registros médicos, fotografias e evidências físicas. Por exemplo, seria interessante ver as calças [da vítima]. Posso supor que elas estariam ensopadas de sangue. É possível examiná-las e passá-las, digamos, a um veterinário, para perguntarmos a ele se esses buracos são consistentes com feridas por mordida de cão.

Como Marimow deixa claro, a primeira tarefa do repórter investigativo é localizar e/ou obter depoimentos e outros tipos de evidências. Loretta Tofani iniciou sua pesquisa sobre agressões sexuais na cadeia do condado realizando entrevistas detalhadas com as fontes que ela entendeu serem as vítimas da sua história.

Eu coletei muito material inútil, mas o que coloquei [na história] eram coisas que descreviam ou corroboravam os crimes; o roteiro em cada um dos casos: onde o indivíduo estava quando o fato ocorreu. Como ocorreu. Como os estupradores se aproximaram dele. Onde estava o guarda. Se ele gritou. Exatamente o que eles fizeram com ele. Exatamente o que eles disseram a ele. Quais eram os nomes das pessoas que fizeram isso com ele. Quanto tempo durou. O que ele fez em seguida - ele recebeu atendimento médico? Todas as perguntas essenciais sobre o que ocorreu quando ele foi estuprado e o que aconteceu a seguir.

Isso foi doloroso para as vítimas, e por isso terminamos falando sobre milhares de coisas diferentes durante aqueles diálogos. Você tem uma namorada? O que você faz na vida real? Onde você cresceu? Quantos irmãos e irmãs você tem? Todas essas coisas me deram um sentido daquela pessoa, mas a maioria delas nunca conseguiu chegar à 
história, porque essas perguntas estavam fora do foco. (...) Quero dizer, eu realmente queria um sentido da pessoa, tal como sua ocupação e posição na sociedade. Era isso que terminava chegando à história.

Os relatos das vítimas forneceram muitas informações com o potencial de se tornarem os fatos do que realmente aconteceu, ainda que nem todas as informações estivessem "em foco". Porém, desde o início do processo de cobertura, a repórter entendeu que as "perguntas essenciais" - as mais relevantes para "o roteiro em cada um dos casos" - diziam respeito não apenas à ocorrência de estupros, mas a problemas do sistema (a cadeia era mal-projetada, por exemplo, e os guardas não podiam ou não queriam reagir), bem como à brutalidade exercida contra vítimas inocentes (pessoas cuja posição "na vida real" não era a de um criminoso contumaz, e sim a de um cidadão comum). Os fatos da agressão (p.ex. os gritos da vítima), juntamente com as suas circunstâncias (p.ex. a localização dos guardas) e as consequências para a vítima, são aquilo que Putnam reconheceria como os "fatos morais" que dotariam os eventos nessa cadeia de significado moral, social e político. Portanto, assim como Ricœur e White haviam predito, a narrativa da repórter - vítimas inocentes deparando-se com um sistema injusto - identificou as perguntas essenciais que essa repórter teria que fazer. Os fatos e a história começaram a emergir simultaneamente a partir dessas entrevistas.

\section{Verificando fatos}

Em seguida, o repórter deve tentar verificar os fatos que emergiram. $\mathrm{O}$ procedimento de Tofani para isso não poderia ser o de comparar os relatos das vítimas com aquilo que realmente ocorreu. Teria que ser o de comparar esses relatos com outros relatos aos quais ela conseguiu acesso. A essência da verificação jornalística, como Tofani deixou claro, é a corroboração entre relatos:

Ainda havia dúvidas em minha mente se eles estavam realmente me dizendo a verdade. Eu mantive a cláusula "Se, de fato, isso ocorreu" à minha volta durante boa parte da história. E assim, o problema passou a ser o de descobrir se eles estavam me dizendo a verdade - se, de fato, isso teria acontecido. Passei um enorme tempo documentando isso.

A primeira tarefa foi conseguir que os funcionários médicos da cadeia conversassem comigo, coisa que não era assim tão fácil. Apenas dois deles consentiram. Eu os visitei em suas casas à noite e fiz-lhes perguntas. Eles estavam bastante incomodados com 
todos os estupros que estavam vendo. Com o tempo, à medida que a confiança cresceu, eles me passaram os registros médicos dessas vítimas de estupro. A partir desses registros médicos, eu pude ver que, de fato, esses homens haviam sido estuprados. (...) Havia claras evidências, tais como sêmen em seus retos, e ferimentos físicos como machucados e ossos quebrados.

Então, eu falei com os próprios estupradores sobre o que eles tinham feito. As histórias corroboraram as histórias das vítimas. Foi apenas quando cheguei ao final da linha - realmente dando corpo a cada história individual - que eu me convenci de que era verdade.

A certeza de Tofani, de que apenas "dando corpo a cada história individual" ela poderia saber a verdade sobre as acusações de estupro é um testemunho da centralidade da corroboração na confecção prática da verdade. Idealmente, ela poderia triangular as fontes - a vítima, o registro médico, o estuprador - ou pelo menos ela poderia comparar duas fontes para dar corpo a cada história. Ainda assim, em um caso, ela contava apenas com as palavras da vítima. Ao discutir esse caso específico, no entanto, a repórter honrou o princípio de corroboração ao admitir o seu descumprimento:

Eu tive dúvidas sobre aquele caso específico até o final, e temo não ter uma boa resposta para como ele entrou na história. Eu conversei com um repórter mais experiente a respeito disso, e eu disse, "Veja, não tenho uma corroboração real". Ele me fez várias perguntas a respeito desse cara - como ele parecia. Eu tinha passado muito tempo conversando com esse cara, e disse que ele realmente parecia perturbado a respeito do seu caso e tinha conseguido descrevê-lo com muitos detalhes. Mesmo quando eu conversei com ele a respeito disso semanas mais tarde, os detalhes permaneciam inalterados, e ele parecia ter bastante claro em sua mente que tudo tinha acontecido daquela maneira. $\mathrm{O}$ outro repórter teve a impressão de que o relato era suficientemente sólido. Eu ainda não tinha certeza, mas confiei nesse julgamento e segui adiante.

Um cientista social poderia identificar a consistência do relato da vítima como uma espécie de confiabilidade por teste/reteste. No entanto, existe outra resposta para como esse caso entrou na história. Esse era o caso de Gary McNamara, um reparador de aparelhos de ar-condicionado de 27 anos de idade que foi estuprado enquanto aguardava julgamento por acusações de roubar bijuterias de uma loja de departamentos. Certa noite, uma semana após sua prisão McNamara foi acordado por um travesseiro pressionado 
contra sua face. Ele foi então jogado no chão frio. Em seguida, de acordo com a reconstrução que Tofani fez de sua história:

"Eu senti algo, acho que foi um punho enfiado em mim", disse McNamara. "Eu fiquei simplesmente aterrorizado".

Ele tinha sido alocado à área 3D com cerca de outros 35 presos, na maioria acusados de roubo armado ou assassinato, de acordo com os guardas da cadeia. A cela de McNamara estava a poucos passos do guarda. Durante o estupro, no entanto, o guarda não conseguia ver o interior da cela de McNamara, porque outros presos haviam coberto a entrada da cela com sacos plásticos pretos, de acordo com McNamara...

Cerca de uma semana mais tarde, McNamara visitou o técnico de medicina da cadeia, um homem que tem menos treinamento do que uma enfermeira certificada, mas McNamara não disse a ele que havia sido estuprado. "Eu tinha medo de voltar para eles", disse, referindo-se aos homens que o estupraram. (TOFANI, 1982b, p. A18)

A história de McNamara, assim como admitiu Tofani, era "instigante" porque continha muitos dos temas que a repórter desejava desenvolver: estupros não relatados, instalações inadequadas da cadeia, e, mais importante, vítimas que não eram criminosos contumazes, mas ficaram sujeitas a uma punição terrível. O princípio da corroboração múltipla se curvou sob o peso do valor do caso para a história mais ampla - mas não se rompeu. Tofani e seu colega permitiram-se estar convencidos da história de McNamara, não apenas por conta de sua consistência, mas também porque ela se encaixa bem com as histórias de outras vítimas capturadas neste lugar infernal. Os fatos morais essenciais dessa história, os fatos da inocência e da culpa, foram corroborados por sua correspondência e coerência interna em meio a uma situação humana muito específica e terrível - o estupro na cadeia - que tinha se tornado dolorosamente reconhecível para a repórter.

A investigação de Pam Zekman sobre o "extermínio" de relatórios criminais mostra ainda mais exemplos do difícil trabalho de verificação jornalística. Primeiro, ela precisou buscar os relatos das vítimas cujos relatórios criminais foram declarados infundados pela polícia, e em seguida ela precisou verificar as alegações das vítimas, de que os crimes haviam sido cometidos de verdade. Assim como Tofani, Zekman pôde passar por diversos casos até encontrar alguns poucos com o nível necessário de 
corroboração. De qualquer maneira, encontrar relatos com a capacidade de corroboração foi uma significativa realização jornalística:

Tivemos muita dificuldade em lidar com a história do estupro, em encontrar vítimas de estupro que pudessem ser entrevistadas e que fossem críveis. (...) Queríamos casos de estupro nos quais havia mais do que apenas as palavras de uma mulher contra os tiras, ou seja, casos nos quais havia algo extra. Tinha o caso de uma moça que incluía os registros do hospital. O departamento de polícia tinha acabado de rejeitar totalmente os registros do hospital, afirmando que ela estava mentindo. Bem, os registros do hospital confirmaram que ela havia sido estuprada. Havia algo tangível, e não a palavra de uma pessoa contra a de outra. E em outro caso, havia uma testemunha que viu o estupro. Quero dizer, não há muitas pessoas que testemunham um estupro, então tínhamos padrões bastante altos. Estamos em busca de casos de estupro nos quais existisse alguma evidência extra.

O trabalho de coletar informações é longo e laborioso, como todos esses repórteres atestaram, mas a corroboração não parece ter sido algo problemático nas suas lembranças dos seus trabalhos. A corroboração parece simplesmente estar ali, entre os relatos, ou então não está. "Suas histórias corroboraram as histórias das vítimas", disse Tofani simplesmente sobre suas longas entrevistas com estupradores, como se ela tivesse encontrado um encaixe preciso ponto a ponto nos relatos. Mas no meio jornalístico, a corroboração raramente significa uma replicação perfeita, ponto a ponto, de relatos. Os repórteres devem estar preparados para ouvir, nas palavras de Marimow, "toda uma gama" de histórias. Realisticamente, então, a corroboração pode significar apenas que certos fatos devem de alguma forma se encaixar uns com outros. Mas quais fatos, e como eles devem se encaixar? As respostas para essas perguntas são exemplos cruciais do conhecimento tácito do ofício jornalístico. Os jornalistas devem conhecer as respostas suficientemente bem para lidarem com o seu trabalho, mas não articulam essas respostas com muita clareza. Apesar disso, os comentários dos repórteres sobre seu trabalho oferecem alguma compreensão sobre os padrões práticos de corroboração nesse domínio de investigação.

É útil iniciar a pergunta sobre "quais fatos?" com o dito de Zekman: "Se este for um fato central, você precisará encontrar uma corroboração, e talvez até mesmo uma corroboração dupla". A noção de "fato crucial" capta habilmente a ideia de que as histórias se desenvolvem a partir de 
algumas situações ou eventos-chave. Em particular, as histórias que serão contadas por esses repórteres, de maneira muito semelhante às histórias contadas nos tribunais, todas giram em torno de delitos específicos ${ }^{3}$. Se as vítimas nas histórias de Tofani e Zekman não tivessem sido estupradas, e se as vítimas na história de Marimow não tivessem sido mordidas por cães da polícia, esses repórteres não teriam qualquer história. Mas como já observamos, o que está "em foco" em cada caso é muito mais do que um mero ataque. Os fatos que remetem às questões essenciais de inocência e culpa também são fatos cruciais. Entre as primeiras perguntas colocadas por Tofani aos registros médicos, assim que ela finalmente pôde obtê-los, estavam as seguintes: "quais foram os ferimentos? Eles se relacionam aos ferimentos que a vítima me relatou?" A natureza e o grau dos ferimentos são cruciais para uma história que se volta não apenas para agressões contra companheiros de cadeia, mas também para a brutalização de homens inocentes. Desta forma, a narrativa emergente designa alguns fatos como cruciais e determina o padrão para a sua verificação. A história determina os fatos para os quais "você precisará encontrar uma corroboração, e talvez até mesmo uma corroboração dupla”.

A questão de "como os fatos se encaixam" pode ser inicialmente abordada com o comentário de Tofani: "Foi apenas quando cheguei ao final da linha - realmente dando corpo a cada história individual - que eu me convenci de que ela era verdadeira". A noção de "dar corpo a cada história individual" traz à mente a útil distinção feita por Stephen Pepper entre corroboração multiplicativa e estrutural (Stephen, 1942). A corroboração multiplicativa requer histórias separadas para chegar a precisamente o mesmo fato, assim como diferentes experimentos científicos conduzem a resultados idênticos. A corroboração estrutural, por sua vez, requer fatos separados para que se encaixem de modo preciso em uma mesma e coerente história.

\footnotetext{
3 Ver Bennett (1979, p. 311-323). A análise de Bennett sobre o ambiente do tribunal mostra que uma "estratégia de história por trás de um caso é executada por meio de uma série de movimentos táticos que indexam as evidências de acordo com a estrutura da história em desenvolvimento" (Bennett, 1979, p. 312). Um tipo de tática é a definição de itens de evidência ou testemunho de uma maneira consistente com (e que adicione elementos à) história que o advogado de defesa deseja contar. É claro, o promotor da acusação trabalha para limitar as definições de evidências ou eventos a termos que se enquadrem dentro de uma definição jurídica de um crime específico, enquanto o advogado de defesa busca definições mais amplas ou alternativas. O que Bennett chama de "a ação central" da história pode requerer uma ou mais definições passíveis de serem cruciais para o caso em questão.
} 
Superficialmente, o trabalho de Tofani parece ser um claro exemplo de corroboração multiplicativa. Diversas fontes distintas de evidências - o testemunho da vítima e do agressor, bem como os registros médicos - conduzem a pelo menos um fato idêntico: estupro. No entanto, a afirmação que a repórter faz de ter corroborado o fato do estupro apoiou-se não apenas pelo uso da palavra estupro nos diversos relatos do ataque. De fato, essa palavra e seus sinônimos nem precisariam ter sido usados. Em vez disso, a afirmação se apoiou no caráter coerente e não-contraditório dos diversos relatos e registros que a repórter obteve a tão duras penas. Quando, por exemplo, o testemunho da vítima foi corroborado pelo registro médico, isso não aconteceu porque dois tipos de evidência se repetiram exatamente com os mesmos itens de informação. Aconteceu porque os dois tipos de evidência forneceram itens distintos, porém relacionados, que se encaixam bem - ou seja, a descrição de um ataque que foi consistente com o registro dos ferimentos. O nível de precisão do encaixe entre as fontes de evidências foi assim satisfatório para justificar o uso de uma descrição específica: estupro.

Desse modo, a corroboração necessária para "dar corpo" a uma história será provavelmente mais estrutural do que multiplicativa. Mas seja essa corroboração estrutural ou multiplicativa, ela se vale de critérios da precisão de encaixe que são difíceis de articular. A despeito da insistência de Tofani em ter encontrado casos com uma corroboração inequívoca, ela admitiu, ainda que muito de leve, que precisou fazer juízos sobre o nível de encaixe entre os itens de informação. "Ao acessar os registros médicos, você quer descobrir se tudo ocorreu quando ele disse que ocorreu", ela afirmou, acrescentando: "Se a informação for imprecisa com uma diferença de um ou dois dias, isso não chega a ser um problema”. Assim, a corroboração de fatos cruciais, que parece a princípio tão fácil, vale-se de uma noção tácita sobre aquilo que constitui um encaixe satisfatório. Talvez qualquer pensador mundano competente concordaria que um ou dois dias não chegam a ser um problema nesse contexto específico. Mas quantos dias, precisamente, seriam?

\section{Estruturando histórias}

Padrões e procedimentos para a corroboração estrutural poderiam desafiar a formalização no jornalismo, mesmo se os jornalistas estivessem dispostos a admitir a constituição mútua entre fatos e histórias. Afinal de contas, os roteiros essenciais à corroboração estrutural estão firmemente 
embasados na sabedoria convencional da cultura, e ainda assim elas são facilmente adaptáveis a aplicações variadas. Um repertório confiável, e ainda assim permutável, de narrativas está à disposição para explicar os caminhos do mundo e para guiar tacitamente a localização e corroboração de fatos relevantes sobre o mundo. Zekman ilustrou o processo por meio de um exemplo hipotético no qual ela tinha uma excelente documentação sobre um fato crucial. Ela realmente tinha aquilo que parecia ser uma prova inequívoca, na forma de um memorando incriminador. Apesar disso, ela sabia que precisava reunir fatos de diversas fontes para chegar a uma das "situações reconhecivelmente humanas" mencionadas por Hayden White:

Um memorando redigido pelo diretor de uma gigantesca empresa imobiliária orientando os seus vendedores a "espalharem pânico" ainda não seria suficiente para que eu contasse a história. Eu iria querer evidências de que isso foi feito. (...) Então eu vou até aquela vizinhança. Saio batendo nas portas e vou descobrir algum proprietário branco que recebeu uma ligação da imobiliária dizendo que os negros estão chegando, e que o valor de sua propriedade cairá. (...) Eu poderia até mesmo colocar pessoas trabalhando como vendedores naqueles escritórios imobiliários para ver se isso é o que ele estava tentando fazer.

Agora, não é todo dia que alguém lhe aparece com um documento na mão. Com mais frequência, o que você vai conseguir é alguém que chega e lhe conta a respeito de uma situação sem ter documentos, e assim você precisará correr atrás dessa parte. Seria uma coisa maravilhosa ter um memorando assim. Ele pode fazer com que você não precise sair em segredo, mas eu ainda iria querer as vítimas. Sem a carta, eu provavelmente precisaria ir em segredo, pois teria que descobrir se essa era mesmo uma política interna do escritório, e não apenas de um vendedor desajuizado.

Da mesma forma como um promotor procuraria determinar motivos, meios e oportunidades, a repórter buscaria incluir na história qualquer evidência de uma intenção ou de uma política delituosa. Ela também procuraria demonstrar instâncias reais de delitos, bem como o efeito desses delitos sobre as vítimas. Tudo isso seria necessário para uma história capaz de corroborar e justificar a acusação de "disseminação do pânico".

O exemplo de Zekman capta o nosso questionamento de que uma história investigativa é estruturada por uma narrativa que serve para identificar e corroborar os fatos cruciais. Esses fatos, por sua vez, dão corpo à narrativa. No exemplo de Zekman, a narrativa é o familiar esquema motivo-ação-con- 
sequência. Nos três relatos que são o nosso foco primário aqui, um elemento essencial da narrativa é o encontro brutal entre um cidadão inocente e um sistema injusto - uma trama que identifica como cruciais não apenas os fatos do encontro em si (o estupro, por exemplo), mas também os muitos fatos da inocência da vítima e da culpa do vilão. E assim, por exemplo, a história de Tofani requer a verificação não apenas dos estupros, mas também de fatos como o contexto e os ferimentos da vítima, as inadequações da cadeia e a indiferença do carcereiro. Por sua vez, todos os fatos se encaixam em um relato crível e instigante a respeito de um problema geral do sistema, que comprovou a realidade desses fatos.

Os repórteres frequentemente usam a metáfora de estarem juntando um quebra-cabeça quando falam sobre a identificação de fatos e a montagem dos mesmos em uma história. A noção de peças de quebra-cabeças entrelaçados, que se encaixam precisamente em uma só imagem é uma metáfora atraente para a corroboração estrutural tanto de fato quanto de história. No entanto, nessa imagem de peças pré-determinadas em seu formato e número, juntando-se na forma de uma figura que também é pré-determinada pela realidade, a metáfora do quebra-cabeça reflete de maneira ingênua demais os pressupostos do realismo metafísico. O conjunto de fatos que parecem se encaixar tão convincentemente em uma história foi moldado por essa mesma história em primeiro lugar, assim como a história foi moldada por uma ordem moral.

Em suma, a narrativa orienta a definição dos fatos; ao mesmo tempo, os fatos devem também justificar a seleção de uma narrativa em particular. Os jornalistas reconhecem que os fatos constrangem suas escolhas, mas eles também reconhecem que têm, sim, escolhas a fazer. "Havia muitas maneiras de contar uma história sobre o fato de que estupros ocorrem na cadeia do condado", como admite Tofani, "mas havia apenas poucas maneiras de contá-la de uma maneira que fosse significativa para as pessoas". Fazer escolhas sábias e moralmente justificáveis, entre as maneiras significativas de se contar uma história, não importa quantas maneiras existam, é central para a busca da verdade que está para ser encontrada entre o realismo e o relativismo.

\section{Resolvendo disjunções}

Argumentar que fato e história são mutuamente constituídos não implica que os repórteres falsifiquem fatos e histórias. A questão aqui é entender os procedimentos jornalísticos de verificação da verdade. E, como argumenta- 
mos, a verificação nesse meio prático significa a corroboração entre múltiplos relatos. Ainda que fatos e histórias se determinem entre si, eles também se constrangem mutuamente, porque os diversos relatos usados pelos repórteres para construírem seus próprios relatos devem concordar de fato (e na história) entre si nas maneiras que esboçamos acima. Mas o que acontece quando os relatos não estão de acordo entre si?

Marimow, por exemplo, confrontou uma coletânea indócil de histórias em sua reportagem sobre os ataques pelos cães policiais. Em suas palavras, ele tinha "toda uma gama" de relatos em cada caso, e ele prontamente admitiu a existência de discrepâncias entre esses relatos. "Acredito que uma história é fiel à verdade quando você foi capaz de fazer tudo o que pôde para conseguir todos os lados de uma história e então sintetizou, analisou e publicou aquilo - sem deixar algo de fora apenas porque isso pode tornar a sua história cinza ao invés de preta", disse. No entanto, a razão mundana insiste que apenas uma história coerente pode ser a verdade e exige que os repórteres resolvam quaisquer discrepâncias capazes de criar uma disjunção significativa na realidade. É claro, os repórteres não podem resolver as discrepâncias testando o relato com "o que realmente ocorreu". Um teste assim não seria possível (se fosse, os repórteres já saberiam a verdade e simplesmente não precisariam se preocupar com relatos discrepantes). Em vez disso, os repórteres se voltam para o seu repertório de estratégias para lidar com erros e mentiras. Isso equivale a dizer que eles invocam os diversos procedimentos do ofício jornalístico para avaliarem a credibilidade dos relatos ${ }^{4}$.

Tofani, por exemplo, julgou que os registros médicos eram altamente críveis a partir da origem burocraticamente certificada de tais registros. "Um registro médico é algo em que você pode confiar, então eu me mantenho com eles, ainda que não houvesse corroboração da parte da vítima”, disse ela. "Não creio que os técnicos médicos tenham uma razão para mentir em um caso desse tipo. Acredito que eles são geralmente bastante profissionais a respeito disso, e era possível ver pelos próprios registros que eles eram feitos de maneira muito cuidadosa”. Ela se valeu amplamente dos registros médicos em um caso no qual a vítima tinha sido vaga a respeito do ataque e não conseguia identificar os seus agressores. "Houve muitos, muitos feri-

Falar de procedimentos para avaliar a credibilidade dos relatos está mais de acordo com a maneira como os jornalistas falariam desses procedimentos, mas falar de procedimentos para construir credibilidade está mais de acordo com o que os jornalistas efetivamente fazem. 
mentos, e a vítima ficou no hospital por um longo tempo", ela disse a respeito do caso. "Como os registros médicos eram tão bons, eu senti que poderia seguir com eles".

Os repórteres frequentemente resumem seus pressupostos sobre a credibilidade de relatos atribuindo um peso metafórico a eles. "Eu atribuiria um enorme peso a um observador treinado, que estivesse no local e não tivesse qualquer razão para inventar algo", disse Marimow, acrescentando: "eu colocaria a mim mesmo no topo dessa escala". Ele atribuiu apenas um pouco menos de peso a testemunhas que, apesar de não serem treinadas, não tinham qualquer interesse pessoal em questão, tal como foi o caso dos Solmssens, que testemunharam o ataque a Joey Loftus, "o garoto" que estava bêbado demais para se lembrar do que tinha ocorrido:

As testemunhas independentes que não conhecem a polícia e não conhecem a vítima, a meu ver, são aquelas que mais provavelmente contariam a verdade. Em casos nos quais existem testemunhas independentes, como os Solmssens no caso Loftus, eu tenderia a me valer mais amplamente dos seus relatos do que dos relatos de qualquer outra pessoa, pelo simples fato de que elas nada têm a proteger. (...) Eu atribuiria um peso muito pequeno àquilo que Joey Loftus disse lembrar. Eu o questionaria cuidadosamente sobre o que ele tinha bebido e o que ele lembrava. Estava claro para mim que a sua recordação era, enquanto eu escrevia, na melhor das hipóteses algo nebuloso e impreciso.

Atribuir pesos às evidências é um princípio útil para o repertório de estratégias de resolução de disjunções por um jornalista. Entretanto, os pesos específicos atribuídos aos diversos relatos variam de um repórter para outro, e até mesmo de uma história para outra. Sob algumas circunstâncias, os repórteres podem atribuir o maior peso a uma evidência visual, tal como uma fita de vídeo, enquanto em outras circunstâncias eles podem atribuir esse peso a documentos jurídicos, ou a registros financeiros. Mas qualquer que seja a hierarquia de pesos, os repórteres avaliam cuidadosamente o peso dos diferentes relatos disponíveis quando querem estabelecer um fato crucial, especialmente quando esses relatos fornecem uma corroboração aquém do satisfatório. Marimow escolheu escrever sobre o ataque a Joey Loftus com base em um relato - de observadores do incidente - ao qual ele atribuiu um peso maior do que o relato da própria vítima. De maneira semelhante, Tofani escolheu escrever sobre um ataque para o qual a vítima só fornecia 
uma corroboração limitada porque tinha um relato ao qual atribuíra um peso maior - os registros médicos.

O conceito de peso contém um conjunto de pressupostos implícitos sobre as condições nas quais erros são cometidos e mentiras são contadas. Uma hierarquia de pesos tanto reflete quanto propicia julgamentos sobre os relatos e suas fontes. Por exemplo, os repórteres atribuem pouco peso às evidências vinculadas aos relatos fornecidos pelos alvos de suas investigações, que, presumidamente, têm muito a esconder. Porém, por uma questão de justiça, os repórteres fazem citações desses relatos, podendo ser até mesmo tão benevolentes (ou cautelosos) a ponto de caracterizar esses relatos como "uma versão dos eventos" ou "uma interpretação dos fatos", como fez Marimow:

Para mim, existe todo um espectro do que é a verdade, e para redigir uma história de maneira justa e completa é preciso conversar com todos os envolvidos, e é preciso obter todas as possíveis interpretações dos fatos. É por isso que penso que é realmente importante deixar claro para o sujeito da sua história que você tem planos de escrever essa história, que você sente fortemente que os fatos são passíveis de interpretação e que, antes de escrevê-la, você quer saber o que ele ou ela tem a relatar.

Quando confrontados com interpretações alternativas dos fatos, os repórteres podem invocar a tradicional ideia jornalística de que eles devem reportar os dois lados e deixar que o público decida. "Creio que o que eu procuro fazer é reunir todos os pontos de vistas possíveis, todos os relatos de um incidente", disse Marimow. "Eu os avalio para produzir o sentido daquilo que eu acredito que realmente aconteceu, e então eu os apresento de maneira tal que os leitores possam se valer da vantagem das informações que eu possuía e que me levaram à minha visão particular". Mas como Marimow sutilmente admitiu, os repórteres não estão dispostos a deixar as suas crenças sobre o que realmente aconteceu em aberto para a dúvida pública. Quando eles proporcionam aos seus leitores "a vantagem das informações" que eles tinham, eles transmitem a sua visão do peso das evidências, e do peso moral a ser alocado às várias interpretações.

Vimos muitos exemplos das estratégias narrativas e retóricas que os repórteres podem usar para transmitir a sua visão do peso que deve ser atribuído às palavras dos vilões das histórias. Pollner chamou essas estratégias de "o ironizar da experiência”, um rótulo apropriado, ainda que pouco poético, 
para um processo que ocorre em tribunais, em redações de jornais e em praticamente todos os outros lugares.

O ironizar da experiência acontece quando uma experiência, tacitamente afirmando ter compreendido o mundo de maneira objetiva, é examinada a partir do ponto de vista de outra experiência, por sua vez honrada como a versão definitiva do mundo ambicionada pela primeira,

escreveu Pollner, de acordo com sua visão do território coberto por Muecke 5 . "A ironia reside na subsequente apreciação de que a experiência inicial não era a representação objetiva que ela originalmente pretendia ou acreditava ser". Fazer com que as palavras dos vilões recaiam sobre eles mesmos dessa maneira é uma importante tática na "política da experiência" jornalística (POLLNER, 1987, p. 71).

Tendo isso em mente, a referência de Marimow a "um amplo espectro do que é a verdade" não deve ser confundido com uma disposição para admitir a possibilidade de "esquemas de descrição" múltiplos e/ou indeterminados. Ainda que negações e outros relatos contraditórios possam ser mencionados na matéria, eles jamais devem ameaçar o compromisso jornalístico com a razão mundana. A "vantagem" que o repórter buscou passar aos seus leitores foi a informação necessária para resolver qualquer aparente disjunção na realidade em prol daquela interpretação verdadeira específica - a sua. De fato, se ele tivesse considerado qualquer dúvida séria acerca de sua interpretação, ele não a teria publicado.

\section{Estabelecendo padrões}

A íntima conexão entre fato e valor frequentemente permeia os julgamentos de relevância. "A decisão de que uma imagem do mundo é verdadeira (...) e responde às perguntas relevantes", como argumentou Putnam, "assenta-se sobre (e revela todo) o nosso sistema de compromissos de valor" (PUTNAM, 1981, p. 201). E assim a conexão entre fato e valor é revelada à medida que esses repórteres buscam respostas para as perguntas mais relevantes ou essenciais - as perguntas que trazem à existência fatos morais relacionados à inocência e à culpa. A conexão é ainda mais revelada à medida que os re-

Ettema e Glasser se referem a D. C. Muecke, cuja discussão sobre "ironia" é central para o capítulo 4 do livro (NE). 
pórteres selecionam casos específicos de vitimização para serem exibidos em suas reportagens, e reúnem esses casos em um padrão coerente de vilania. Um padrão de casos é crucial para o ponto principal de qualquer história que diz respeito não apenas ao delito individual, mas também ao colapso institucional, por exemplo, no sistema de justiça criminal.

Demonstrar um padrão de colapso institucional é algo que requer múltiplos casos, mas nem todos os casos servem para isso. Os critérios para a seleção dos casos que farão parte do relatório conclusivo às vezes incluem a representatividade dos casos. "Se for uma história que afeta toda uma cidade, e você não quer que as pessoas suponham que ela afeta apenas a comunidade negra, então você buscará um espectro de vítimas que contribuam a este ponto", disse Zekman. "Você faz essas escolhas quando você as tem, mas você nem sempre as tem". Ainda que as considerações quanto à representatividade possam constranger as escolhas dos repórteres, elas não determinam essas escolhas. Tofani, por exemplo, decidiu logo no início do projeto que a seleção dos casos de estupro não podia ser deixada ao sabor do acaso:

Uma das maiores decisões, senão a maior de todas em relação à sequência de estupros de cadeia, foi escolher as vítimas de estupro sobre as quais eu iria escrever. Nos primeiros estágios daquela história, eu não era capaz de perceber que uma cadeia significava que as pessoas não haviam sido condenadas por crimes e eram juridicamente inocentes. Em outras palavras, eu não entendia a distinção entre uma cadeia e uma prisão. Eu pensava que todas aquelas pessoas estavam ali por motivos como roubo à mão armada ou assassinato - essas coisas realmente terríveis. Uma parte da razão pela qual eu pensava aquilo era por causa do método que eu tinha escolhido para tentar coletar os nomes das vítimas de estupro. Eu andava pelo tribunal hora após hora, parando os advogados no saguão e dizendo, "Escuta, você tem clientes que foram estuprados? Você pode me dizer quem eles são?"

Eu até consegui obter nomes com os advogados... mas com esse método, eu só estava pegando gente barra pesada. A primeira vítima com quem eu falei era um cara que tinha estuprado cinco mulheres. Eu só estava encontrando pessoas que tinham cometido crimes realmente horrendos, e foi apenas mais adiante que eu descobri que muitas dessas pessoas estavam detidas por furtos em lojas ou por dirigirem embriagadas. Eu tomei a decisão de que as pessoas sobre as quais eu iria escrever eram pessoas juridicamente inocentes, ou então pessoas que estavam detidas por crimes leves: as pessoas que cometeram furtos em lojas e os motoristas embriagados. Eu também iria incluir exemplos de pessoas que estavam ali por coisas muito sérias, mas eu iria selecionar as pessoas inocentes para comporem a maioria dos meus casos. 
Tofani não estava fechando os olhos para a ideia de representatividade, mas as suas decisões não foram guiadas por uma lógica científica de amostragem. Afinal de contas, sua meta não era apresentar um perfil geral de todos os casos que representavam o universo do estupro. Em vez disso, sua meta era sublinhar os casos que poderiam provocar uma indignação moral por parte dos seus leitores - os casos de "pessoas juridicamente inocentes que estavam detidas por crimes leves". Ainda que ela tenha buscado estabelecer a frequência de ataques na cadeia, ela não procurou determinar a porcentagem de ataques a "vítimas inocentes" em contraposição a "vítimas culpadas". Dada a ambiguidade da inocência nesse meio, a tarefa teria sido difícil. De fato, isso foi desnecessário porque a indignação pública não é ativada por um número ou percentual específico de casos, e sim por alguns poucos casos envolventes. Não se trata de uma lógica científica pautada por estimativas e parâmetros do que efetivamente acontece, e sim por uma lógica moral em busca de histórias daquilo que pode acontecer. A repórter capturou bem a lógica de suas escolhas. "Essas vítimas eram pessoas com as quais os leitores poderiam se identificar", ela disse. "Você sabe, 'Poderia ter sido o meu filho, detido por dirigir embriagado"'.

Assim, para apontar o padrão dos casos, os repórteres buscam por um padrão específico nos casos selecionados. Assim como Tofani, Marimow buscou casos com características específicas que pudessem sugerir um colapso institucional. "Quando selecionei os casos sobre a unidade K-9, eu precisei julgar primeiramente se o uso de um cão era apropriado para o caso”, disse. "Existe um padrão suficientemente claro para sugerir que há muitos ou poucos policiais da K-9 na Filadélfia que sejam incapazes de controlar os seus cães? Caso exista esse padrão, quais casos o ilustram?” O repórter reconheceu que o conceito de padrão é problemático. Ele admitiu que não existe uma fórmula para determinar a presença de um padrão, mas estava disposto a defender o padrão como uma realidade empírica:

A mim me parece que mesmo sem tratarmos a questão de uma maneira matemática, se você tem diversos ataques que foram questionados por testemunhas independentes, e esses ataques ocorreram contra pessoas sem registros criminais ou sem um histórico de violência, então você já tem o suficiente para começar a pensar em uma história. Para mim, nove casos de pessoas juridicamente inocentes ou factualmente inocentes, apoiados por testemunhas independentes, foram o suficiente para que eu começasse a pensar em uma "história". 
Quando se trata de um padrão real, então ele se mostrará no mundo. Para mim, um padrão é um modo recorrente de conduta. Se "vez após vez" um cão de um policial morde uma pessoa acidentalmente, então, para mim, isso é um padrão. "Vez após vez" pode ser três ou quatro vezes, mas se o cão de um policial ataca de três a quatro cidadãos por acidente ao longo de um ano, então para mim esse é um padrão de ataque que se presta a ser questionado.

Marimow fez sua defesa dos padrões da realidade empírica dentro do contexto de sua afirmação de que não fazia juízos morais, e sim apenas juízos profissionais em relação à importância de sua história. Mas a despeito de seu cuidado em apresentar seus juízos sobre os padrões como livre de valores, a realidade empírica do padrão depende claramente de diversos fatos morais significativos: muitas vítimas são inocentes e o uso dos cães é injustificado. A importância de tais fatos morais para o padrão se tornou explícita à medida que o repórter introduziu o padrão no primeiro artigo da série: "Aquele padrão: alguns poucos policiais e alguns poucos cães contabilizam um número desproporcional de ataques e mordidas por cães" (Marimow, 1984, p. 3).

Alguns poucos parágrafos adiante, o repórter apresenta os detalhes do padrão como um conjunto de pontos. Por exemplo:

- Os cães policiais da unidade K-9 têm repetidamente atacado e mordido homens e mulheres desarmados sem qualquer antecedente criminal.

- Ao contrário dos padrões aceitos em outras unidades K-9, os cães da Filadélfia não são treinados para soltarem as suas vítimas logo após a mordida inicial...

- As mordidas dos cães têm deixado ferimentos profundos e deformadores, além de órgãos mutilados, que requerem hospitalizações caras e prolongadas.

A única conclusão que pode ser razoavelmente alcançada a partir desse padrão é outro fato ainda mais visivelmente moral: "O resultado", como disse o repórter, "é que isso é um problema".

$\mathrm{Na}$ história do estupro na cadeia, a repórter não se referiu explicitamente a "um padrão", mas sua apresentação das conexões entre os casos é muito parecida com a história dos ataques caninos. A sua lista resumida de pontos é um tema recorrente das reportagens investigativas:

De acordo com os guardas e com os presos, os estupros e ataques sexuais na cadeia do condado têm algumas características em comum: 
- Ocorrem em celas fora da vista de qualquer guarda...

- Os estupros são particularmente violentos...

- Muitos dos estupradores são acusados ou condenados por assassinato ou roubo armado, e são colocados junto com pessoas que estão aguardando um encaminhamento por acusações de crimes não-violentos (Tofani, 1982a, p. A18).

A apresentação do padrão mostra um instigante conjunto de corroboração tanto múltipla quanto estrutural para os seguintes fatos morais fundamentais: o sistema publico falhou; cidadãos inocentes podem ser e têm sido suas vítimas; e os policiais culpados devem ser responsabilizados não apenas por desonestidade, mas também por indiferença e hipocrisia.

\section{Conhecendo e contando a verdade}

Não estamos questionando a afirmação de que essas reportagens investigativas são verdadeiras. Porém, temos argumentado que concepções simplistas da verdade desviam-se não apenas daquilo que os filósofos tipicamente dizem, mas também daquilo que os próprios repórteres fazem. Portanto, estamos questionando o que significa dizer que essas reportagens são verdadeiras.

Em primeiro lugar, questionamos qualquer afirmação de que essas reportagens são verdadeiras porque os repórteres as construíram precisamente com o objetivo de corresponder "ao que realmente aconteceu”. Os repórteres não poderiam ter conseguido isso, pois não tiveram acesso ao que realmente aconteceu. Eles não tinham algo a que seus relatos pudessem corresponder, a não ser outros relatos - os relatos das vítimas, dos vilões, das testemunhas e assim por diante. Assim, a afirmação de saber a verdade sobre o que ocorreu não pode assentar-se sobre a afirmação de que uma correspondência foi alcançada em relação à realidade, mas tão somente sobre um rigoroso processo de corroboração entre os relatos.

Também questionamos qualquer afirmação de que essas reportagens são verdadeiras porque os repórteres primeiramente descobriram os fatos e então os montaram no formato de uma história. Os repórteres não poderiam ter feito isso, porque os fatos e as histórias não existem independentemente entre si. Os fatos são as peças a partir das quais as histórias são montadas, mas as histórias são necessárias para determinar a relevância de fatos em potencial, e de modo a corroborar estruturalmente esses fatos. É apenas no 
contexto de uma história coerente que as "perguntas essenciais" podem ser formuladas e os "fatos cruciais" podem ser identificados e corroborados. Assim, a tentativa de conhecer a verdade começa e termina com as histórias.

Por fim, questionamos qualquer afirmação de que essas reportagens são verdadeiras porque os repórteres evitaram o viés resultante da intrusão de valores no seu trabalho. Os repórteres não poderiam ter feito isso, porque as respostas para as perguntas essenciais são facilmente reconhecíveis como os fatos morais da inocência e da culpa. Como os fatos só podem ser "cruciais" no contexto de uma história, e em relação a uma escala de valores morais, então os valores necessariamente estruturam o procedimento de verificação. Saber e dizer a verdade, ao fim e ao cabo, permanecem subordinados aos valores que os repórteres compartilham com suas comunidades.

Não estamos negando que há verdade a ser buscada. Porém, questionamos que aqueles que buscam uma verdade definida nos termos de um realismo metafísico ingênuo, estão buscando o impossível e, portanto, estão tentando muito pouco. Esse paradoxo é facilmente resolvido: como o realismo ingênuo demanda uma correspondência exata entre afirmações independentes de valores e uma realidade independente da mente, ele subverte a consideração cuidadosa do que os buscadores da verdade prática devem realmente procurar. $\mathrm{O}$ realismo ingênuo, por exemplo, permite aos jornalistas afirmar que a corroboração simplesmente está (ou não está) aí. Os padrões de corroboração permanecem embutidos no conhecimento tácito do ofício. Ademais, o realismo ingênuo permite aos jornalistas afirmar que primeiro eles encontram os fatos e, em seguida, escrevem suas histórias a partir desses fatos. As narrativas que ajudam a constituir os fatos permanecem submersas em um sentido comum culturalmente compartilhado que não é examinado. E, por fim, o realismo ingênuo permite aos jornalistas ignorar a conexão crucial entre relevância e valores. As forças morais que dão vida não apenas ao jornalismo investigativo, mas a todo o empreendimento intelectual da investigação social prática, permanecem obscurecidas pelo pressuposto de que os fatos podem existir sem valores ou os valores sem fatos.

No que diz respeito à verdade, o jornalismo investigativo parece melhor na prática do que na teoria. Se nada é tão prático quanto uma boa teoria, então esse gênero de jornalismo tem pouco a dizer a respeito da verdade. Se, por outro lado, nada é tão teórico quanto à boa prática, então o jornalismo 
investigativo tem algumas lições úteis a respeito do papel dos valores na busca prática da verdade.

\section{Referências bibliográficas}

BENNETT, Lance. 1979. "Rhetorical transformation of evidence in criminal trials: creating grounds for legal judgment”. Quarterly Journal of Speech, n. 65, p. 311-323.

GOLDSTEIN, Leon J. 1976. Historical knowing. Austin: University of Texas Press.

MARIMOW, William K. 1984. "A City roughed up: the K-9 cases". Philadelphia Inquirer, 15 de abril, p. 3.

PEPPER, Stephen C. 1942. World hypotheses: a study in evidence. Berkeley: University of California Press.

POLLNER, Melvin. 1987. Mundane reason: reality in everyday and sociological discourse. New York: Cambridge University Press.

PUTNAM, Hilary. 1981. Reason, truth and history. New York: Cambridge University Press.

RICOEUR, Paul. 1965. History and truth. Evanston, Ill.: Northwestern University Press.

TOFANI, Loretta. 1982a. “Terror behind bars". Washington Post, parte 1 da série "Rape in the county jail: Prince George’s hidden horror", 26 de setembro, p. A18.

. 1982b. “The repairman”. Washington Post, parte 1 da série "Rape in the county jail: Prince George's hidden horror”, 26 de setembro, p. A18.

WHITE, Hayden. 1978. The tropics of discourse: essays in cultural criticism. Baltimore, Md.: Johns Hopkins University Press.

1987. The content of the form: narrative discourse and historical representation. Baltimore, Md.: Johns Hopkins Press.

\section{Resumo}

O texto de Ettema e Glasser discute as formas de seleção das informações e produção das histórias jornalísticas. A questão central, para os autores, é o que significa dizer que as reportagens jornalísticas são verdadeiras. Em outras palavras, a que critérios e valores correspondem as histórias que são vistas como verdadeiras. Essa análise é parte da discussão sobre a relação entre valores e fatos no jornalismo. A objetividade é vista como um dispositivo que legitima determinados discursos e permite apresentar julgamentos como fatos. Resulta de acordos quanto aos valores que constituem as premissas dos julgamentos. 
Os padrões morais que estão na base da produção do noticiário transformam-se em fatos que podem, então, ser reportados com distanciamento.

Palavras-chave: jornalismo; objetividade; padrões morais; seleção das informações; verdade.

\section{Abstract}

This text discusses the forms of selection of information and production of news stories. For its authors, the central question in this respect is what it means to say that news reports are true. In other words, what are the criteria and values corresponding to stories seen as true. The analysis is part of the wider discussion on the relationships of values to facts in journalism. Objectivity is seen as a device to legitimate some discourses and allows for the presentation of opinions as facts. It results from negotiations about the values that are the assumptions of opinions. Moral standards that are at the foundations of news productions become facts that may, then, be reported with exemption.

Key words: journalism; objectivity; moral standards; information selection; truth. 